\title{
is Research Square \\ Treatment of recurrent Wilms tumor: a 10-year experience of a single center in Southern China
}

\section{Hong Jiang}

The First Affiliated Hospital of Sun Yat-sen University

\section{Pengfei Gao}

Sun Yat-sen University First Affiliated Hospital

\section{Huadong Chen}

Sun Yat-sen University First Affiliated Hospital

\section{Zhihai Zhong}

Sun Yat-sen University First Affiliated Hospital

\section{Zhichong Zhang}

Sun Yat-sen University First Affiliated Hospital

\section{Jinbiao She}

Sun Yat-sen University First Affiliated Hospital

Juncheng Liu ( 1446447201@qq.com)

The First Affiliated Hospital of Sun Yat-sen University

\section{Research article}

Keywords: Wilms' tumor, nephroblastoma, recurrence, metastasis

Posted Date: June 15th, 2019

DOI: https://doi.org/10.21203/rs.2.10343/v1

License: @ (i) This work is licensed under a Creative Commons Attribution 4.0 International License. Read Full License 


\section{Abstract}

Background: This study aimed to report our 10-year experiences on the treatment of recurrent Wilms tumor (WT) to improve the therapeutic outcome of recurrent WT in China. Patients and Methods: From August 2006 to August 2017, 14 patients (7 males and 7 females) with recurrent Wilms' tumor treated at our center were included. Their medical records were reviewed. Results: Primary WT were mainly diagnosed at the age of 1-3 years (50\%). The main histology of primary WT was unclassified types (42.9\%), followed by blastemal types (35.7\%). Four cases did not receive standardized postoperative chemotherapy after the initial surgery. Recurrence mostly occurred within the first year after initial surgery (57.1\%). The recurrent WT mainly occurred at the primary location and ipsilateral lymph nodes (35.7\%), followed by extensive peritoneal metastasis (28.6\%). Eleven patients underwent surgery for complete resection of the recurrent lesions. There were 9 patients achieved event-free survival for 1 year 2 months to 9 years. Three, one, one and one patients died of extensive intraperitoneal metastases, brain metastasis, peritoneal metastasis, severe intestinal obstruction vomiting, electrolyte imbalance and tumor invasion of the spinal cord, respectively. Conclusions: Individualized multimodal treatment can effectively improve long-term survival of the patients of recurrence WT.

\section{Background}

Wilms tumor (WT), also known as nephroblastoma, accounts for $90 \%$ of all pediatric kidney cancers $[1,2]$. The incidence of WT in children with an age under 15 years is approximately 1:10,000 worldwide [2], but is geographically variable. Epidemiological studies report that incidence of WT is higher in Africa than in Asia, and intermediate in Caucasian in North America [3,4]. Even though WT can also be diagnosed in adolescents or adults, approximately $75 \%$ of WT cases are diagnosed before the age of 5 years, and the median age at initial diagnosis is 3.5 years $[5]$.

The current standard therapy for WT patients is a multimodal treatment, namely a combination of surgery and chemotherapy, with the additional radiotherapy for high-risk patients, which has resulted in a significant improvement in therapeutic outcomes [6]. The 2-year event-free survival rates of WT patients in developed countries have reportedly up to $85-90 \%[7,8]$. However, event-free survival in developing countries remains unsatisfactory due to economic factors and non-standard therapy [9].

According to the post-nephrectomy histology, WT can be classified into epithelial type, mesenchymal type, mixed type, blastemal type, and anaplastic type [10]. Patients with an anaplastic type of WT are regarded as of unfavorable histology and high-risk for a worse prognosis [2]. Yao et al. have reported that WT patients with an unfavorable histology have a significantly higher recurrence rate than those with a favorable histology [11]. On the other hand, tumor recurrence is also a crucial risk factor associated with poor outcomes for WT patients [12,13]. The second and third National Wilms Tumor Studies (NWTS) trials II and III have shown that the 3-year survival rate after WT recurrence is markedly reduced to $30 \pm 3 \%$ [14].

The recurrence rate for WT has been reported to be around 10 to $20 \%$ [11,15-17]. So far, published literature on the treatment of recurrent WT in China is still limited. The current study aimed to report our experiences with the treatment of children with recurrent WT at our center over the last ten years, with the purpose to improve the therapeutic outcome of recurrent WT in China.

\section{Methods}




\section{Patients}

A total of 14 patients with recurrence of Wilms' tumor were treated at Department of Pediatric Surgery, the First Affiliated Hospital of Sun Yat-sen University from August 2006 to May 2016. The medical records of these patients were retrospectively reviewed. Patients' demographics, records of diagnosis, surgery, histology, chemotherapy, radiotherapy, sites of recurrence and interval from primary surgery to recurrence were collected. This study was approved by the institutional review board of the First Affiliated Hospital of Sun Yat-Sen University, and written informed consent was obtained from the patients.

\section{Surgical management}

The flow chart of treatment strategy for recurrent Wilms tumor in our center was shown in the Fig. 1. For patients who can undergo surgery, the recurrent tumor should be completely excised without rupture as much as possible. Regarding surgical incision, the abdominal transverse incision was considered for patients with abdominal recurrence. The incision must be large enough to fully expose the whole abdominal cavity. The original surgical incision in the initial surgery could be used and appropriately extended if full exposure can be achieved. For patients with pulmonary metastases, thoracotomy or thoracoscopic surgery could be considered. Thoracoabdominal incision could be considered if patients with tumor embolism. The tumor, including adjacent suspicious malignant tissue and regional lymph nodes and all the swollen lymph nodes should be removed. If the tumor was connected to an adjacent organ (such as the spleen, colon, pancreas), complete tumor resection was performed by partial resection of the adjacent organs. If complete tumor resection cannot be achieved, the patients should receive chemotherapy first, followed by the radical surgery. Within one week after surgery, the tumor staging was determined again according to the findings of surgical exploration and pathological examination.

\section{Radiotherapy}

The radiotherapy was started within 9 days after surgery. Patients with recurrent abdominal disease underwent tumor bed radiotherapy with a total dose of $10.8 \mathrm{~Gy}(1.8 \mathrm{~Gy} /$ time$)$. For patients with tumor greater than $3 \mathrm{~cm}$ (diameter), the total dose could be increased to $21.6 \mathrm{~Gy}$. The total dose of whole abdominal radiotherapy was 10.5 Gy (1.5 Gy/time). Patients with distant metastasis received radiotherapy in the metastatic region.

\section{Chemotherapy}

Chemotherapy regiments were determined according to whether or not the patients had received the standard chemotherapy before the tumor recurrence. The chemotherapy dose should be reduced to $50 \%$ and $75 \%$ for the patients aged $<10$ months and 10-12 months, respectively. In the preoperative chemotherapy, the patients without prior standard chemotherapy in the initial surgery received two sessions of chemotherapy containing actinomycin D (Act-D) $15 \mu \mathrm{g} / \mathrm{kg} \mathrm{d} 1-5$ + vincristine (VCR) $1.5 \mathrm{mg} / \mathrm{m}^{2} \mathrm{~d} 1$ + adriamycin (ADR) $50 \mathrm{mg} / \mathrm{m}^{2} \mathrm{~d} 1$, and the patients were evaluated if they can receive surgery. If the tumor volume did not reduce after two sessions of above chemotherapy or for patients with prior chemotherapy in the initial surgery, the patients should receive two sessions of alternate chemotherapy (cyclophosphamide (CTX) $1.2 \mathrm{~g} / \mathrm{m}^{2} \mathrm{~d} 1+\mathrm{VCR} 1.4 \mathrm{mg} / \mathrm{m}^{2}+\mathrm{ADR} 50 \mathrm{mg} / \mathrm{m}^{2} \mathrm{~d} 1$ and Carboplatin (CBP) 
$400 \mathrm{mg} / \mathrm{m}^{2} \mathrm{~d} 1+$ Vepesid (VPI6) $100 \mathrm{mg} / \mathrm{m}^{2} \mathrm{~d} 1-\mathrm{d} 5$ ). If the assessment shows that the patient still cannot undergo surgery, the chemotherapy regimen needed to be changed.

In the postoperative chemotherapy, for patients without prior chemotherapy, the regiments of chemotherapy were as follows (24 weeks):

VCR $1.4 \mathrm{mg} / \mathrm{m}^{2}$ (maximal: $2 \mathrm{mg}$ ) qw $\times 10$ at $0^{\text {th }}-9^{\text {th }}$ week, $12^{\text {th }}, 15^{\text {th }}, 18^{\text {th }}, 21^{\text {th }}$, and $24^{\text {th }}$ week; Act-D $15 \mu \mathrm{g} / \mathrm{kg} \mathrm{d} 1-5$ at $0^{\text {th }}, 6^{\text {th }}, 12^{\text {th }}, 18^{\text {th }}$ and $24^{\text {th }}$ week; $4^{\prime}-0$-Tetrahydropyranyladriamycin (THP-ADM) $45 \mathrm{mg} / \mathrm{m}^{2}, \mathrm{~d} 1$ at $3^{\text {th }}, 9^{\text {th }}, 15^{\text {th }}, 21^{\text {th }}$ week. For patients with prior chemotherapy, the regiments were alternate chemotherapy (CTX+VCR+ADR and CBP+VP16) for 24 weeks, followed by radiotherapy.

For patients with standard preoperative and postoperative chemotherapy in the initial surgery or those with no response to $A C T-D+V C R+A D R$, the regiments were alternate chemotherapy CAV (CTX+VCR+THP-ADM) and CE (Carboplatin + Etoposide), 3 weeks apart.

The detailed regiments were as follows: CAV: CTX $1.2 \mathrm{~g} / \mathrm{m}^{2} \mathrm{~d} 1$; VCR: $1.5 \mathrm{mg} / \mathrm{m}^{2}, \mathrm{~d} 1$, THP-ADM $50 \mathrm{mg} / \mathrm{m}^{2} \mathrm{~d} 1$; CE: CBP $400 \mathrm{mg} / \mathrm{m}^{2} \mathrm{~d} 1 ; \mathrm{VP} 16: 100 \mathrm{mg} / \mathrm{m}^{2} \mathrm{~d} 1-5$.

\section{Results}

\section{Demographic and clinical characteristics of patients}

From August 2006 to August 2017, there were 14 patients diagnosed with recurrent Wilms' tumor and treated at our center, including 7 males and 7 females. The demographic and clinical characteristics of primary tumor of the 14 patients were summarized in Table 1. The median age at initial diagnosis was 30 months. There were 3 cases, 7 cases and 3 case initially diagnosed with WT at $<1$ year (case 9, 11, 12), 1-3 years (case 1, 2, 3, 5, 6, 7, 10, 13) and 4-7 years (case 4, 8, 14), respectively. Four patients had intraoperative spillage of tumor cells (case $8,9,12,14$ ) at the initial surgery. The first histological examinations showed 5 blastemal predominant types (case 4, 5, 8, 9,14), 2 mixed types (case 1, 3), one epithelial type (case 11), and 6 unclassified types (case 2, 6, 7, 10, 12, 13). Three cases did not receive standardized postoperative chemotherapy after the first surgery (case 1, 2, 12).

\section{Tumor recurrence}

The clinical characteristics of relapsed tumor of the 14 patients were summarized in Table 2. Tumor recurrence was mainly found via regular postoperative imaging examinations $(n=12)$, or the examinations after the incidence of intestinal obstruction $(n=2)$. Regarding the relapse-free interval, eight patients had a recurrence within one year 1 after the initial surgery, while six patients had recurrence more than one year after initial surgery. As for the location of recurrence, there were 5 cases with primary location and ipsilateral lymph nodes (case 2, 3, 6, 10, 11), 4 cases with extensive peritoneal metastasis (case $8,9,12,14$ ), one with primary location and pulmonary metastases at the same time (case 1, Fig. 2), one with pulmonary metastasis (case 4), one with pulmonary (Fig. 3), pleural and brain (Fig. 4) metastases at different times (case 5), one occurred in the residual kidney (case 7), and one with recurrent tumor invading into the pelvic cavity, spinal canal and spinal cord (case 13). 


\section{Treatment of recurrent Wilms' tumor and therapeutic outcomes}

Except for two patients with extensive peritoneal metastasis combined with intestinal obstruction $($ case 8,12$)$ and one case had tumor invasion of spinal canal and cord (case 13) who cannot be treated with surgery, the remaining 11 patients all underwent surgery for complete resection of the recurrent lesions. Ten cases underwent radiotherapy (case $1,2,3,4,5,6,8,9,10,14$ ), and three of them received whole abdominal radiotherapy (case 8,9 , 14). As shown in Table 1, the second histological examinations demonstrated that there were one blastemal types (case 1), 3 mesenchymal types (case 2, 6, 9), one mixed type (case 14), 4 unclassified types (case 3, 4, 11, 13), and 3 necrotic tissue (case $5,7,10$ ).

After treatment, 8 patients achieved event-free survival for 25 months to 11 years (cases 1 [Fig. 4], 2, 3, 4, 6, 7, 10, 11). Six cases died after treatment. Four patients had extensive intraperitoneal metastases (cases $9,12,14$ ); one (case 5) had brain metastasis; one (case 8) had peritoneal metastasis, severe intestinal obstruction vomiting, electrolyte imbalance; and one had tumor invasion of the spinal canal and spinal cord (case 13).

\section{Discussion}

It has been shown that early recurrence at $<12$ months after initial diagnosis is a poor prognostic factor for recurrent WT [14]. Among the 14 recurrent WT in this study, 8 cases (57.1\%) and 5 cases (35.7\%) had a recurrence within the first and the second year after the initial surgery, respectively. This finding is consistent with the previous report that most recurrent WT occur within the first 2 years after the initial diagnosis [14]. In our series, a case had a recurrence at 5 years after the initial surgery, which is a late recurrence case defined as recurrence longer than 5 years after the initial diagnosis. However, long-term regular follow-up is necessary for all WT patients since the extremely rare cases such as long-delayed late recurrences longer than 20 years after the initial diagnosis have been reported $[18,19]$.

In the current study, there were 5 cases of blastemal WT at first histology, accounting for $35.7 \%$ of all the subtypes. This result indicated that patients with a blastemal WT may have a higher risk of tumor recurrence than those with other subtypes. Meanwhile, Kinoshita et al. have shown that the blastemal WT exhibits a significantly worse prognosis (5-year overall survival) as compared with other subtypes [20]. These observations also indicated that patients with a blastemal WT are required to be followed up more frequently.

In this study, tumor recurrence mostly occurred in the ipsilateral peritoneum $(5 / 14,35.7 \%)$, followed by the extensive peritoneal metastasis (4/14, 28.6\%). Intracranial metastasis was rare. Notably, all the 4 cases with extensive peritoneal metastasis had a history of preoperative/intraoperative tumor rupture or spillage at the initial surgery. Specifically, case 8,9 , and 14 had a preoperative spontaneous tumor rupture while case 12 had an intraoperative tumor rupture. It is known that whole abdominal radiotherapy is indicated for WT patients with extensive intraperitoneal metastasis [21]. Three (case $8,9,14$ ) of 4 patients underwent whole peritoneal radiotherapy, but all the four patients still died of intraperitoneal metastasis. To prevent intraoperative tumor rupture, the surgical incision should be large enough to fully expose the tumor. In addition, the surgical operation should be gentle to avoid the rupture of tumor capsule. Furthermore, for patients with a large tumor, preoperative chemotherapy should be considered to reduce the tumor volume, and the surgery could be conducted after tumor shrinkage. When the bloody ascites or tumor rupture or spillage is observed during the first surgery, the patient is 
suggested to receive an enhanced chemotherapy regimen and early intraperitoneal radiotherapy to reduce the risk of extensive peritoneal metastasis. As for the second surgery, for patients with extensive peritoneal metastasis, it is difficult to achieve radical resection of all tumors. Thus the lesions can only be removed as much as possible under the premise of the preservation of normal organ function. Meanwhile, if intestinal obstruction is observed during surgical exploration, ostomy could be performed to improve the postoperative quality of life of the patient.

In the current study, one patient (case 2) had a recurrent tumor on the residual ureter in the lesional side, indicating that the initial surgical resection (removal of ipsilateral kidney and ureter) was not thoroughly carried out. In the second surgery, the recurrent tumor and the residual tissue at left kidney were completely resected. After postoperative chemotherapy and radiotherapy, the patient has been achieving disease-free survival for 31 months. Meanwhile, 3 patients (case $3,10,11$ ) did not receive removal of the lymph nodes at the initial surgery, which may contribute to the tumor recurrence. Case 3 received the initial surgery in the other hospital. Case 10 and case 11 were the early cases of our hospital and the importance of removing the lymph nodes was not emphasized at that time.

In our series, case 7 presented primary WT combined with tumor thrombus into the superior vena cava but thrombectomy was not performed at the initial surgery. The patient received standardized postoperative chemotherapy. At 25 months after the first surgery, tumor recurrence was found at ipsilateral lymph node and the tumor thrombus continued to enlarge, which might contribute to the tumor recurrence. The tumor thrombus was then successfully removed at the second surgery. For WT patients combined with tumor emboli, thrombectomy should be included in the preoperative assessment before the initial surgery. In addition, thoracotomy open-heart surgery could be conducted for thrombectomy if necessary.

In addition to the initial surgery for WT, standardized postoperative chemotherapy (sufficient dosage, sufficient treatment course, and regular interval) is also crucial for reducing the incidence of recurrence. In our series, three cases of recurrent WT did not receive standardized postoperative chemotherapy after initial surgery. Of them, case 1 received postoperative chemotherapy at the half of the recommended dose. Case 2 underwent only one session of postoperative chemotherapy, thereby both the dosage and course were insufficient. Case 13 received postoperative chemotherapy at an insufficient dosage. The non-standard chemotherapy may contribute to the tumor recurrence.

At present, individualized multimodal treatment combining chemotherapy, surgery, radiotherapy remains the standard treatment for recurrence WT, and which can significantly improve long-term survival of the patients [13]. In this study, except for 3 patients which cannot be treated with surgical management, the remaining 11 patients all underwent surgery for complete resection of the recurrent lesions. There were 8 patients achieved event-free survival for 25 months to 11 years. Nevertheless, three, one, one and one patients died of extensive intraperitoneal metastases, brain metastasis, peritoneal metastasis, severe intestinal obstruction vomiting, electrolyte imbalance and tumor invasion of the spinal cord, respectively.

\section{Conclusions}

In summary, our study suggested that non-standard surgery for the primary WT and non-standard postoperative chemotherapy after the first surgery may contribute to recurrent WT. In China, therefore, the importance of standardized treatments for primary WT should be emphasized and strictly performed to reduce the incidence of 
recurrent WT, especially for the local hospitals without the department of pediatric surgery as well as pediatric urologists and pediatric urologic surgeons.

\section{List Of Abbreviations}

WT: Wilms tumor; NWTS: National Wilms Tumor Studies; CTX: cyclophosphamide; CBP: Carboplatin

\section{Declarations}

\section{Ethics approval and consent to participate}

This study was approved by the institutional review board of the First Affiliated Hospital of Sun Yat-Sen University. The written informed consent was obtained from the patients.

\section{Consent for publication}

Written informed consent was obtained from the parents/legal guardians of patients for publication of this study and any accompanying images. A copy of the written consent is available for review by the Editor of this journal.

\section{Availability of data and material}

All the data and material were presented in the main paper.

\section{Competing interests}

The authors declare that they have no competing interests.

\section{Funding}

None declared.

\section{Authors' contributions}

We declare that all the listed authors have participated actively in the study and all meet the requirements of the authorship. $\mathrm{HJ}$ and $\mathrm{JL}$ designed the study and wrote the protocol, PG performed research/study, HC contributed important reagents, ZZ managed the literature searches and analyses, ZZ and JS undertook the statistical analysis, $\mathrm{HJ}$ wrote the first draft of the manuscript. All authors approved the final version of the manuscript.

\section{Acknowledgements}

None. 


\section{References}

1. Szychot E, Apps J, Pritchard-Jones K. Wilms' tumor: biology, diagnosis and treatment. Transl Pediatr. 2014; 3:12-24.

2. Erginel B. Wilms Tumor and Its Management in a Surgical Aspect Codon Publications, 2016.

3. Stiller CA, McKinney PA, Bunch KJ, Bailey CC, Lewis IJ. Childhood cancer and ethnic group in Britain: a United Kingdom children's Cancer Study Group (UKCCSG) study. Br J Cancer. 1991; 64:543-8.

4. Breslow N, Olshan A, Beckwith JB, Green DM. Epidemiology of Wilms tumor. Med Pediatr Oncol. 1993; 21:17281.

5. Breslow NE, Beckwith JB, Perlman EJ, Reeve AE. Age distributions, birth weights, nephrogenic rests, and heterogeneity in the pathogenesis of Wilms tumor. Pediatr Blood Cancer. 2006; 47: 260-7.

6. Metzger ML, Dome JS. Current therapy for Wilms' tumor. Oncologist 2005; 10:815-26.

7. D'Angio GJ: The National Wilms Tumor Study: a 40 year perspective. Lifetime Data Anal. 2007; 13:463-70.

8. Davidoff AM. Wilms' tumor. Curr Opin Pediatr. 2009; 21:357-64.

9. Ekenze SO, Agugua-Obianyo NE, Odetunde OA. The challenge of nephroblastoma in a developing country. Ann Oncol Off J Eur Soc Med Oncol. 2006; 17:1598-600.

10. Vujanić GM, Sandstedt B: The pathology of Wilms' tumour (nephroblastoma): the International Society of Paediatric Oncology approach. J Clin Pathol. 2010; 63:102-9.

11. Yao W, Li K, Xiao X, Gao J, Dong K, Xiao X, Lv Z. Outcomes of Wilms' Tumor in Eastern China: 10 Years of Experience at a Single Center. J Investig Surg. 2012;25:181-5.

12. Pinkerton CR, Groot-Loonen JJ, Morris-Jones PH, Pritchard J. Response rates in relapsed Wilms' tumor. A need for new effective agents. Cancer. 19991; 67:567-71.

13. Park ES, Kang HJ, Shin HY, Ahn HS. Improved survival in patients with recurrent Wilms tumor: the experience of the Seoul National University Children's Hospital. J Korean Med Sci. 2006; 21: 436-40.

14. Grundy P, Breslow N, Green DM, Sharples K, Evans A \& D’Angio GJ. Prognostic factors for children with recurrent Wilms' tumor: results from the Second and Third National Wilms' Tumor Study. J Clin Oncol. 1989; 7: 638-47.

15. Shamberger RC, Guthrie KA, Ritchey ML, Haase GM, Takashima J, Beckwith JB, D’Angio GJ, Green DM, Breslow NE. Surgery-related factors and local recurrence of Wilms tumor in National Wilms Tumor Study 4. Ann Surg. 1999; 229: $292-7$.

16. Li W, Kessler P, Yeger H, Alami J, Reeve AE, Heathcott R, Skeen J, Williams BR. A gene expression signature for relapse of primary wilms tumors. Cancer Res. 2005; 65:2592-2601.

17. Sen S, Kadamba P, Al-AbdulAaly M, Mammen KE, Ahmed S. Results of Wilms? tumour management in two tertiary-care hospitals in Asia. Pediatr Surg Int. 1998; 13: 42-4. 
18. Lee SY, Kim KR, Park JY, Ro JY. Wilms' Tumor with long-delayed recurrence: 25 years after initial treatment. Korean J Urol. 2012;53:288-92.

19. Senetta R, Macrì L, Pacchioni D, Castellano I, Cassoni P, Bussolati G. Late recurrence of Wilms? tumour with exclusive skeletal muscle phenotype 23 years after primary diagnosis. Virchows Arch. 2007;450:115-118.

20. Kinoshita Y, Suminoe A, Inada H, Yagi M, Yanai F, Zaizen Y, Nishi M, Inomata Y, Kawakami K, Matsufuji H, Suenobu S, Handa N, Kohashi K, Oda Y, Hara T, Taguchi T. The prognostic significance of blastemal predominant histology in initially resected Wilms? tumors: A report from the Study Group for Pediatric Solid Tumors in the Kyushu Area, Japan. J Pediatr Surg. 2012; 47:2205-9.

21. PDQ Pediatric Treatment Editorial Board PPTE. Wilms Tumor and Other Childhood Kidney Tumors Treatment (PDQ®): Health Professional Version National Cancer Institute (US), 2002.

\section{Tables}

Table 1. The demographic and clinical characteristics of primary tumor 


\begin{tabular}{|c|c|c|c|c|c|c|c|c|c|c|}
\hline \begin{tabular}{|c|} 
Case \\
no.
\end{tabular} & Sex & \begin{tabular}{|c|}
$\begin{array}{c}\text { Age at } \\
\text { initial } \\
\text { diagnosis } \\
\text { (months) }\end{array}$ \\
\end{tabular} & $\begin{array}{l}\text { Initial } \\
\text { stage }\end{array}$ & Initial visit & $\begin{array}{l}\text { Initial } \\
\text { imaging } \\
\text { findings }\end{array}$ & \begin{tabular}{|c|}
$\begin{array}{c}\text { Preoperative } \\
\text { chemotherapy }\end{array}$ \\
\end{tabular} & \begin{tabular}{|c|} 
1st surgical \\
pathology
\end{tabular} & Postoperative chemotherapy & \begin{tabular}{|c|} 
Initial \\
radiotherapy
\end{tabular} & $\begin{array}{c}\text { Relapse- } \\
\text { free } \\
\text { interval } \\
\text { (months) }\end{array}$ \\
\hline 1 & $\mathrm{~F}$ & 32 & II & $\begin{array}{c}\text { Admission } \\
\text { due to right } \\
\text { abdominal } \\
\text { mass } \\
\end{array}$ & $\begin{array}{l}\text { Right } \\
\text { wilms } \\
\text { tumor }\end{array}$ & No & mixed & $\begin{array}{c}\text { Chemotherapy for stage II Wilms } \\
\text { tumor with good prognosis, } \\
\text { halved dose }\end{array}$ & No & 3.3 \\
\hline 2 & $\mathrm{~F}$ & 35 & I or II & \begin{tabular}{|c|} 
Admission \\
due to left \\
abdominal \\
mass \\
\end{tabular} & $\begin{array}{l}\text { Wilms } \\
\text { tumor }\end{array}$ & No & unclassified & $\begin{array}{c}\text { One session of chemotherapy for } \\
\text { stage III Wilms tumor with good } \\
\text { prognosis }\end{array}$ & No & 9 \\
\hline 3 & $\mathrm{~F}$ & 34 & I or II & $\begin{array}{c}\text { Visit due to } \\
\text { abdominal } \\
\text { mass }\end{array}$ & $\begin{array}{l}\text { Wilms } \\
\text { tumor }\end{array}$ & No & mixed & $\begin{array}{c}\text { Chemotherapy for stage II Wilms } \\
\text { tumor with good prognosis, } \\
\text { standardized }\end{array}$ & No & 6.5 \\
\hline 4 & $M$ & 45 & III & \begin{tabular}{|c|} 
Visit due to \\
repeated \\
fever for 2 \\
months \\
\end{tabular} & $\begin{array}{l}\text { Wilms } \\
\text { tumor! }\end{array}$ & \begin{tabular}{|c|}
$\begin{array}{c}\text { Two sessions } \\
\text { of } \\
\text { preoperative } \\
\text { chemotherapy }\end{array}$ \\
\end{tabular} & blastemal & $\begin{array}{c}\text { Chemotherapy for stage III Wilms } \\
\text { tumor with good prognosis, } \\
\text { standardized }\end{array}$ & Yes & 15 \\
\hline 5 & $M$ & 29 & III & $\begin{array}{c}\text { Visit due to } \\
\text { fever }\end{array}$ & $\begin{array}{l}\text { Wilms } \\
\text { tumor }\end{array}$ & No & blastemal & $\begin{array}{c}\text { Chemotherapy for stage III Wilms } \\
\text { tumor with good prognosis, } \\
\text { standardized }\end{array}$ & No & 14 \\
\hline 6 & $\mathrm{~F}$ & 26 & III & \begin{tabular}{|c|} 
Physical \\
examination
\end{tabular} & \begin{tabular}{|l|} 
Left renal \\
mass with \\
vena cava \\
tumor \\
thrombus \\
\end{tabular} & \begin{tabular}{|c|}
$\begin{array}{c}\text { Four sessions } \\
\text { of }\end{array}$ \\
preoperative \\
chemotherapy
\end{tabular} & unclassified & No & No & 25 \\
\hline 7 & M & 12 & V & $\begin{array}{c}\text { Visit due to } \\
\text { abdominal } \\
\text { mass }\end{array}$ & $\begin{array}{l}\text { Bilateral } \\
\text { Wilms } \\
\text { tumor] }\end{array}$ & \begin{tabular}{|c|} 
Three \\
sessions of \\
preoperative \\
chemotherapy \\
\end{tabular} & unclassified & $\begin{array}{c}\text { Seven sessions of chemotherapy } \\
\square \mathrm{VCR}+\mathrm{ACTD}+\mathrm{ADM} \square\end{array}$ & No & 60 \\
\hline 8 & $\mathrm{~F}$ & 81 & III & \begin{tabular}{|l|} 
Visit due to \\
acute \\
abdominal \\
pain after \\
falling
\end{tabular} & $\begin{array}{l}\text { Mixed } \\
\text { density } \\
\text { mass in } \\
\text { the right } \\
\text { kidney }\end{array}$ & $\begin{array}{c}\text { Two sessions } \\
\text { of } \\
\text { preoperative } \\
\text { chemotherapy }\end{array}$ & blastemal & $\begin{array}{l}\text { Six sessions of chemotherapy } \\
\text { (VCR+ACTD/VCR+ADM) }\end{array}$ & Yes & 5 \\
\hline 9 & $M$ & 9.75 & III & \begin{tabular}{|c|} 
Repeated \\
fever for 1 \\
month \\
abdominal \\
mass \\
\end{tabular} & \begin{tabular}{|l|} 
Left renal \\
mass \\
occupation
\end{tabular} & No & blastemal & $\begin{array}{c}\text { Chemotherapy for stage III Wilms } \\
\text { tumor with good prognosis, } \\
\text { standardized }\end{array}$ & Yes & 4.25 \\
\hline 10 & $M$ & 29 & IV & $\begin{array}{c}\text { Visit due to } \\
\text { abdominal } \\
\text { mass }\end{array}$ & $\begin{array}{l}\text { Right } \\
\text { Wilms } \\
\text { tumor }\end{array}$ & No & unclassified & $\begin{array}{c}\text { Chemotherapy for stage IV Wilms } \\
\text { tumor (Dactinomycin+VCR) }\end{array}$ & No & 18 \\
\hline 11 & $M$ & 6 & 1 & \begin{tabular}{|c|}
$\begin{array}{l}\text { Vist due to } \\
\text { left upper } \\
\text { abdominal } \\
\text { mass }\end{array}$ \\
\end{tabular} & $\begin{array}{c}\text { Left wilms } \\
\text { tumor }\end{array}$ & No & epithelial & $\begin{array}{l}\text { Six sessions of chemotherapy } \\
\text { (VCR +ACTD) }\end{array}$ & No & 9 \\
\hline 12 & $\mathrm{~F}$ & 5 & III & $\begin{array}{c}\text { Visit due to } \\
\text { abdominal } \\
\text { mass }\end{array}$ & NA & No & unclassified & Non-standardized & No & 4 \\
\hline 13 & $M$ & 31 & III & $\begin{array}{c}\text { Visit due to } \\
\text { abdominal } \\
\text { mass }\end{array}$ & $\begin{array}{c}\text { Left Wilms } \\
\text { tumor }\end{array}$ & $\begin{array}{c}\text { Two sessions } \\
\text { of } \\
\text { preoperative } \\
\text { chemotherapy }\end{array}$ & unclassified & $\begin{array}{c}\text { Chemotherapy for stage III Wilms } \\
\text { tumor with good prognosis, } \\
\text { standardized }\end{array}$ & No & 15 \\
\hline 14 & $\mathrm{~F}$ & 45 & IV & $\begin{array}{c}\text { Visit due to } \\
\text { abdominal } \\
\text { mass and } \\
\text { abdominal } \\
\text { pain }\end{array}$ & $\begin{array}{c}\text { Left wilms } \\
\text { tumor }\end{array}$ & No & blastemal & $\begin{array}{c}\text { Chemotherapy for stage IV Wilms } \\
\text { tumor with good prognosis }\end{array}$ & No & 6 \\
\hline
\end{tabular}


Table 2. The clinical characteristics of relapsed tumors

Page $11 / 16$ 


\begin{tabular}{|c|c|c|c|c|c|c|c|}
\hline $\begin{array}{c}\text { Case } \\
\text { No. }\end{array}$ & $\begin{array}{l}\text { Location of } \\
\text { recurrence }\end{array}$ & $\begin{array}{l}\text { Imaging findings } \\
\text { at recurrence }\end{array}$ & $\begin{array}{c}\text { Post-relapse treatment } \\
\text { procedure }\end{array}$ & $\begin{array}{l}\text { 2nd surgical } \\
\text { pathology }\end{array}$ & Radiotherapy & $\begin{array}{c}\text { Survival } \\
\text { time } \\
\text { after } \\
\text { relapse } \\
\text { (months) }\end{array}$ & Prognosis \\
\hline 1 & $\begin{array}{l}\text { Right } \\
\text { retroperitoneum, } \\
\text { lung }\end{array}$ & $\begin{array}{l}\text { CT showed } \\
\text { masses during } \\
\text { chemotherapy }\end{array}$ & $\begin{array}{l}\text { After surgery, } 9 \text { sessions of } \\
\text { alternate chemotherapy } \\
\text { (CBP+VP16 AND } \\
\text { CTX+VCR+ADM) }\end{array}$ & Blastemal & $3 d$-crt 10.8 gy & 30 & $\begin{array}{l}\text { Treatment finish, } \\
\text { survival }\end{array}$ \\
\hline 2 & $\begin{array}{c}\text { Left } \\
\text { retroperitoneum }\end{array}$ & \begin{tabular}{|c|} 
CT showed \\
occupying \\
lesions in the left \\
renal region, \\
multiple small \\
lymph nodes in \\
the \\
retroperitoneum \\
\end{tabular} & $\begin{array}{c}\text { Preoperative chemotherapy: } 4 \\
\text { sessions of VAA regimen. } \\
\text { Postoperative chemotherapy } \\
\text { :ACT+VDS regimen }\end{array}$ & Mesenchymal & 3d-crt 10.8 gy & 31 & $\begin{array}{l}\text { Treatment finish, } \\
\text { survival }\end{array}$ \\
\hline 3 & $\begin{array}{c}\text { Right } \\
\text { retroperitoneum }\end{array}$ & $\begin{array}{l}\text { CT revealed a } \\
\text { mass }\end{array}$ & $\begin{array}{l}\text { Two sessions of preoperative } \\
\text { chemotherapy; standardized } \\
\text { postoperative chemotherapy }\end{array}$ & Unclassified & $3 d-c r t 10.8$ gy & 39 & $\begin{array}{l}\text { Treatment finish } \\
\text { survival }\end{array}$ \\
\hline 4 & $\begin{array}{l}\text { Left upper } \\
\text { pulmonary lobe }\end{array}$ & \begin{tabular}{|c|} 
Regular $\mathrm{CT}$ \\
examination \\
revealed a mass
\end{tabular} & $\begin{array}{c}\text { Two sessions of preoperative } \\
\text { chemotherapy, high-risk regimen. } \\
\text { After surgical removal of lung } \\
\text { metastatic lesions, standardized } \\
\text { postoperative chemotherapy } \\
\text { was performed, high-risk } \\
\text { regimen. }\end{array}$ & Unclassified & $3 d$-crt 10.8 gy & 67 & $\begin{array}{l}\text { Treatment finish }] \\
\text { survival }\end{array}$ \\
\hline 5 & $\begin{array}{l}\text { Right lower } \\
\text { pulmonary lobe } \\
\text { (1st recurrence), } \\
\text { right lower pleura } \\
(2 \mathrm{nd}), \text { brain (3rd) }\end{array}$ & \begin{tabular}{|c|} 
Regular $\mathrm{CT}$ \\
examination \\
revealed a mass
\end{tabular} & $\begin{array}{l}\text { Two sessions of preoperative } \\
\text { chemotherapy, high-risk regimen. } \\
\text { After surgical removal of lung } \\
\text { metastatic lesion, } 4 \text { sessions of } \\
\text { postoperative chemotherapy, } \\
\text { CAV regimen. Standardized } \\
\text { postoperative chemotherapy } \\
\text { was performed for the } \\
\text { metastasis of right lower pleura. }\end{array}$ & $\begin{array}{l}\text { Necrotic } \\
\text { tissue }\end{array}$ & 2MRT $10.8 \mathrm{~Gy}$ & 18 & $\begin{array}{l}\text { Dead, cause: left } \\
\text { frontal lobe } \\
\text { cerebral } \\
\text { hemorrhage } \\
\text { (acute phase) }\end{array}$ \\
\hline 6 & $\begin{array}{l}\text { Abdominal aortic, } \\
\text { right renal lymph } \\
\text { nodes }\end{array}$ & \begin{tabular}{|c|} 
Regular $\mathrm{CT}$ \\
examination \\
revealed a mass
\end{tabular} & $\begin{array}{c}\text { Five sessions of alternate } \\
\text { CAV/CE chemotherapy and } \\
\text { standardized postoperative } \\
\text { chemotherapy } \\
\end{array}$ & Mesenchymal & 3D-CRT $10.8 \mathrm{~Gy}$ & 25 & $\begin{array}{c}\text { Treatment finish, } \\
\text { survival }\end{array}$ \\
\hline 7 & $\begin{array}{l}\text { Right residual } \\
\text { kidney }\end{array}$ & \begin{tabular}{|c|} 
Regular $\mathrm{CT}$ \\
examination \\
revealed a mass
\end{tabular} & $\begin{array}{c}\text { One session of preoperative } \\
\text { chemotherapy } \\
(\mathrm{VCR}+\mathrm{ACTD}+\mathrm{ADM})\end{array}$ & $\begin{array}{l}\text { Necrotic } \\
\text { tissue }\end{array}$ & None & 36 & $\begin{array}{l}\text { Treatment finish }] \\
\text { survival }\end{array}$ \\
\hline 8 & $\begin{array}{l}\text { Intraperitoneal, } \\
\text { lymph nodes of } \\
\text { right ventricular } \\
\text { diaphragmatic wall, } \\
\text { pleura, peritoneum } \\
\text { and abdominal } \\
\text { multiple } \\
\text { metastases }\end{array}$ & $\begin{array}{l}\text { CT showed } \\
\text { abdominal } \\
\text { effusion; } \\
\text { swollen lymph } \\
\text { nodes at right } \\
\text { palpebral area }\end{array}$ & $\begin{array}{c}\text { Two sessions of postoperative } \\
\text { chemotherapy } \\
\text { (carboplatin+VP16) }\end{array}$ & NA & $\begin{array}{c}\text { Whole } \\
\text { abdominal } \\
\text { radiotherapy,3D- } \\
\text { CRT, } 30 \mathrm{~Gy}\end{array}$ & 9 & $\begin{array}{l}\text { Dead, cause: } \\
\text { peritoneal } \\
\text { metastasis, severe } \\
\text { intestinal } \\
\text { obstruction } \\
\text { vomiting, } \\
\text { electrolyte } \\
\text { imbalance }\end{array}$ \\
\hline 9 & $\begin{array}{l}\text { Extensive } \\
\text { peritoneal } \\
\text { metastasis }\end{array}$ & $\begin{array}{l}\text { B ultrasound } \\
\text { showed } \\
\text { abdominal } \\
\text { effusion } \\
\end{array}$ & $\begin{array}{c}\text { Abdominal puncture showed } \\
\text { bloody ascites. Exploratory } \\
\text { laparotomy revealed extensive } \\
\text { peritoneal metastasis. }\end{array}$ & Mesenchymal & \begin{tabular}{|c|} 
Whole \\
abdominal \\
radiotherapy,3d- \\
crt $10.5 \mathrm{gy}$ \\
\end{tabular} & 2 & $\begin{array}{l}\text { Dead, cause: } \\
\text { extensive } \\
\text { intraperitoneal } \\
\text { metastases } \\
\end{array}$ \\
\hline 10 & Right abdomen & \begin{tabular}{|c|} 
B ultrasound \\
showed right \\
abdominal mass
\end{tabular} & $\begin{array}{c}\text { Six sessions of postoperative } \\
\text { chemotherapy } \\
\text { (carboplatin+VP16) }\end{array}$ & $\begin{array}{l}\text { Necrotic } \\
\text { tissue }\end{array}$ & $\begin{array}{l}\text { Right-flank } \\
\text { abdominal } \\
\text { radiotherapy, } \\
21.6 \mathrm{~Gy} \\
\end{array}$ & 132 & $\begin{array}{l}\text { Treatment finish[ } \\
\text { survival }\end{array}$ \\
\hline 11 & $\begin{array}{l}\text { Left } \\
\text { retroperitoneum, }\end{array}$ & \begin{tabular}{|c|} 
Regular MRI \\
examination \\
revealed a mass
\end{tabular} & Surgical resection & Unclassified & None & 108 & $\begin{array}{l}\text { Treatment finish } \\
\text { survival }\end{array}$ \\
\hline
\end{tabular}




\begin{tabular}{|c|c|c|c|c|c|c|c|}
\hline & $\begin{array}{l}\text { Abdominal aorta, } \\
\text { inferior vena cava }\end{array}$ & & & & & & \\
\hline 12 & $\begin{array}{l}\text { Liver, extensive } \\
\text { peritoneal } \\
\text { metastasis }\end{array}$ & NA & $\begin{array}{c}\text { After two session of } \\
\text { chemotherapy, patient still } \\
\text { developed extensive peritoneal } \\
\text { metastasis, and then the patient } \\
\text { gave up the treatment. }\end{array}$ & $\mathrm{Na}$ & None & 4 & $\begin{array}{l}\text { Dead, cause: } \\
\text { extensive } \\
\text { intraperitoneal } \\
\text { metastases }\end{array}$ \\
\hline 13 & $\begin{array}{c}\text { Retroperitoneum, } \\
\text { Pelvic large tumor } \\
\text { invading into L4 S3 } \\
\text { spinal canal and } \\
\text { L5/S1 spinal cord }\end{array}$ & $\begin{array}{c}\text { Identifying a } \\
\text { mass } 6 \text { months } \\
\text { after treatment }\end{array}$ & $\begin{array}{c}\text { Four sessions of alternate } \\
\text { chemotherapy for anaplastic } \\
\text { Wilms tumor (CBP+VP16) and } \\
(\mathrm{CTX}+\mathrm{V} C \mathrm{C}+\mathrm{ADM}) \text {, tumor size } \\
\text { was not reduced. Tumor cannot } \\
\text { be removed by surgery. }\end{array}$ & Unclassified & None & 38 & $\begin{array}{l}\text { Dead, cause: } \\
\text { tumor invasion of } \\
\text { the spinal canal } \\
\text { and spinal cord }\end{array}$ \\
\hline 14 & $\begin{array}{c}\text { Extensive } \\
\text { peritoneal pelvic } \\
\text { metastasis }\end{array}$ & $\begin{array}{l}\text { B-ultrasound } \\
\text { revealed a mass } \\
\text { after } \\
\text { chemotherapy }\end{array}$ & $\begin{array}{l}\text { Five sessions of preoperative } \\
\text { chemotherapy, but extensive } \\
\text { peritoneal metastasis could not } \\
\text { be radically excised. }\end{array}$ & Mixed & \begin{tabular}{|c|} 
Whole \\
abdominal \\
radiotherapy;3d- \\
crt $12.6 \mathrm{gy}$
\end{tabular} & 8 & $\begin{array}{l}\text { Dead, cause: } \\
\text { extensive } \\
\text { intraperitoneal } \\
\text { metastases }\end{array}$ \\
\hline
\end{tabular}

\section{Figures}

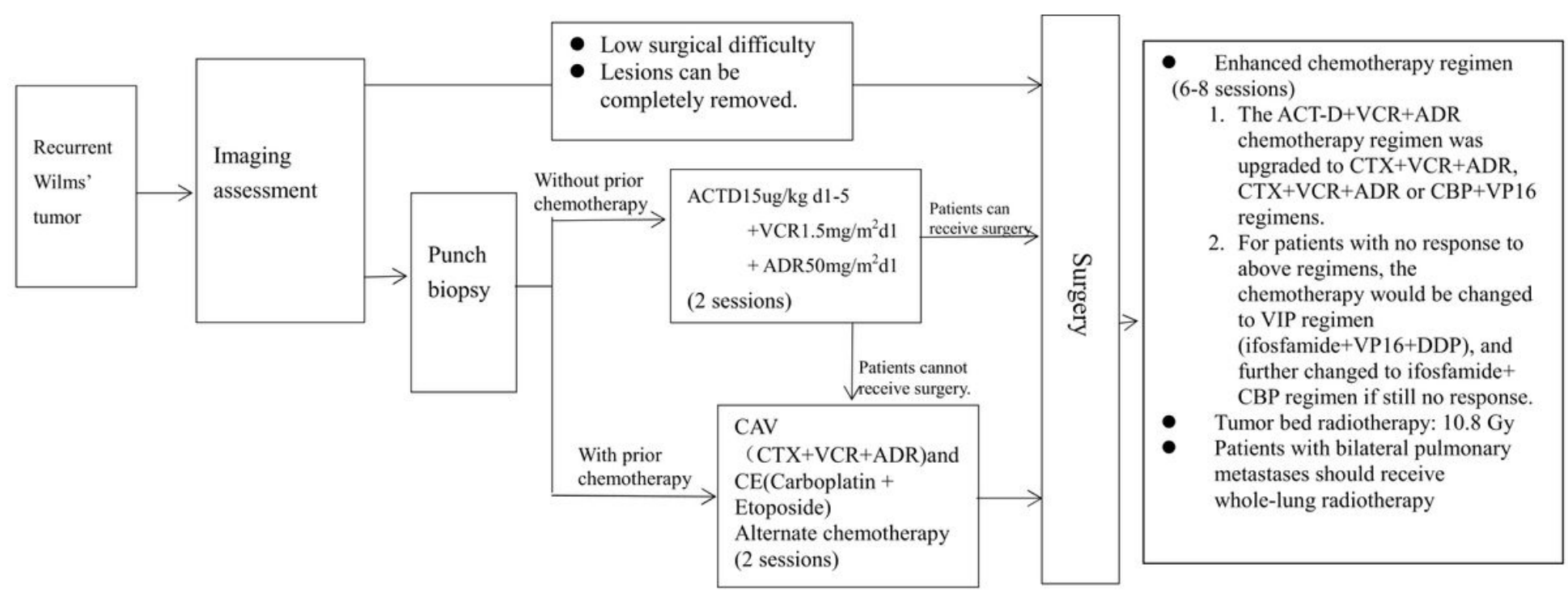

\section{Figure 1}

Flowchart of the treatment strategy for recurrent Wilms tumor. 


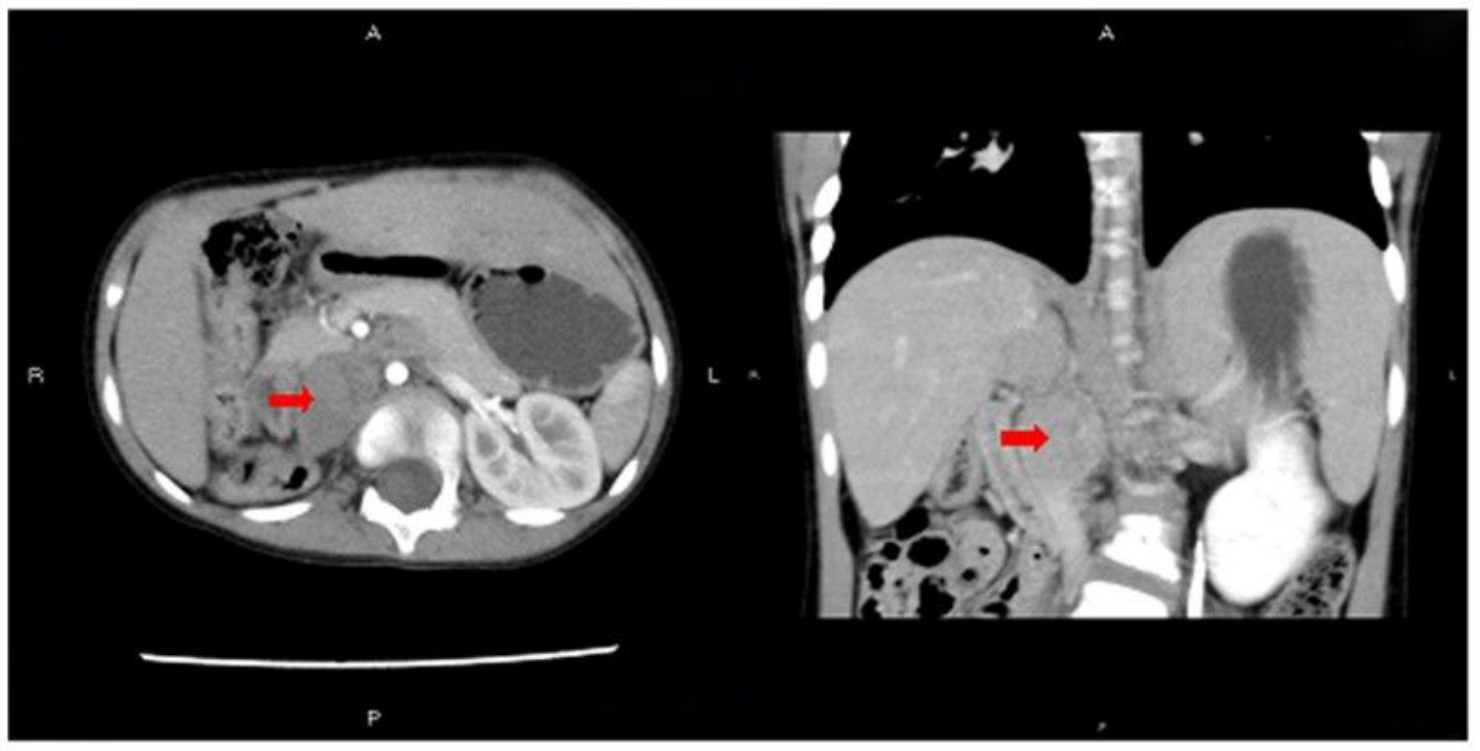
$\mathrm{C}$
D

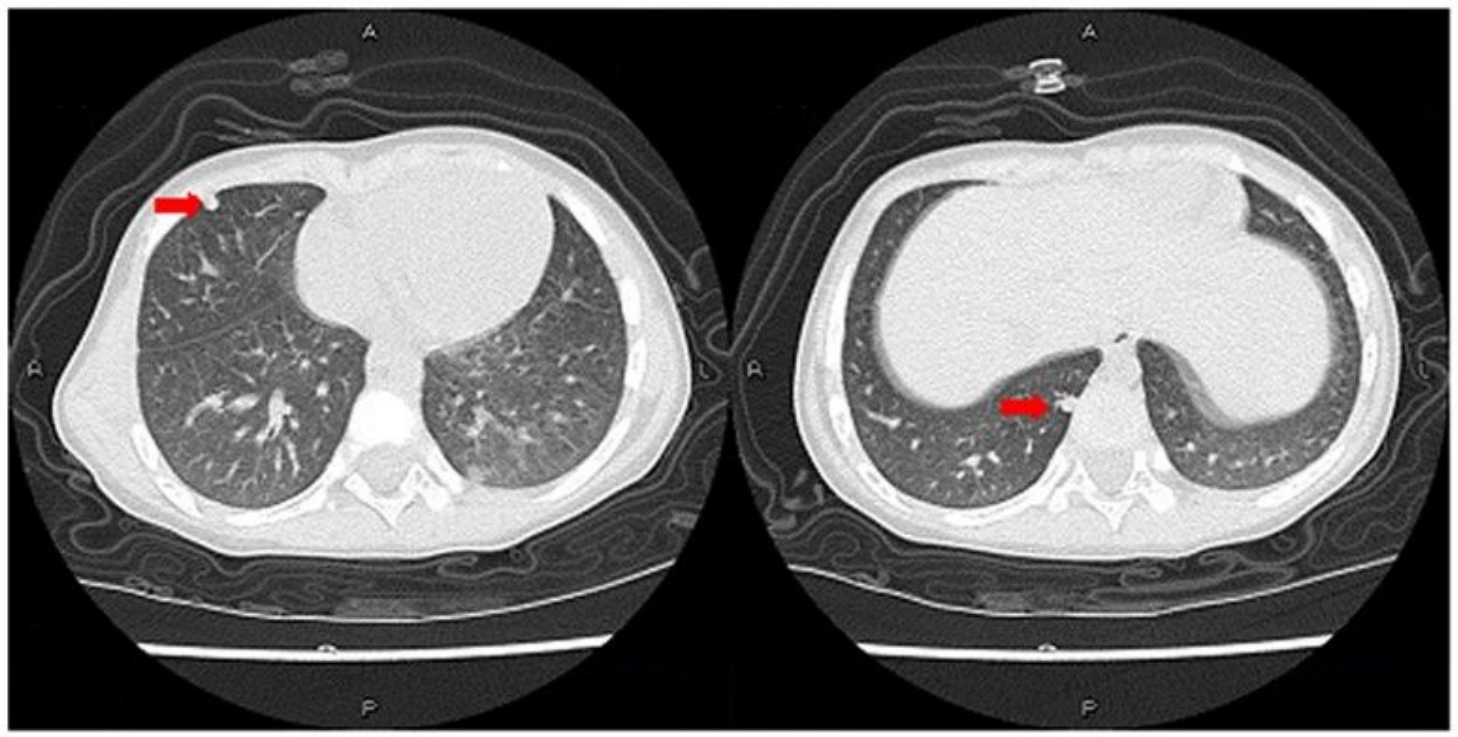

Figure 2

The preoperative CT findings of case 1. (A-B) The CT images showed that the right kidney was absence, and an irregular huge soft tissue mass could be observed in the right kidney area and retroperitoneum. Enhanced CT showed irregular enhancement. (C-D) The CT images showed multiple nodules in the posterior basal segments of right middle lobe of lung and lower lung lobe, indicating pulmonary metastasis. 
A

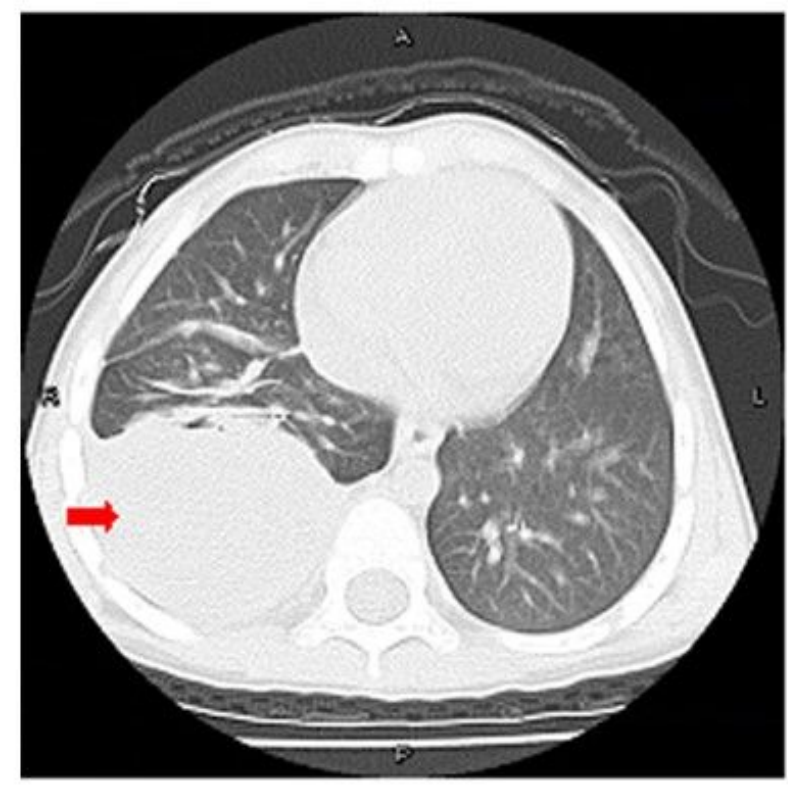

$\mathrm{C}$

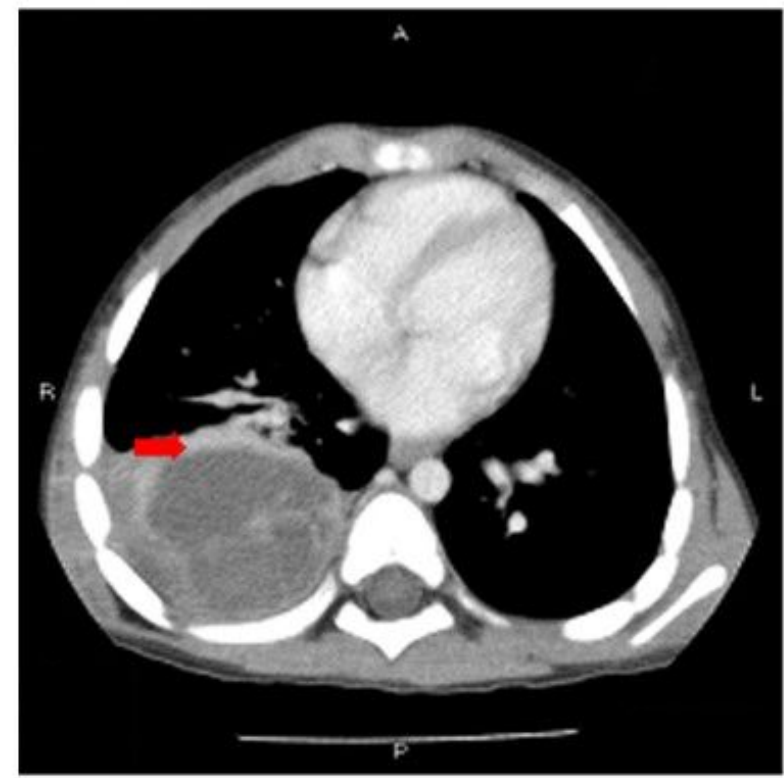

B

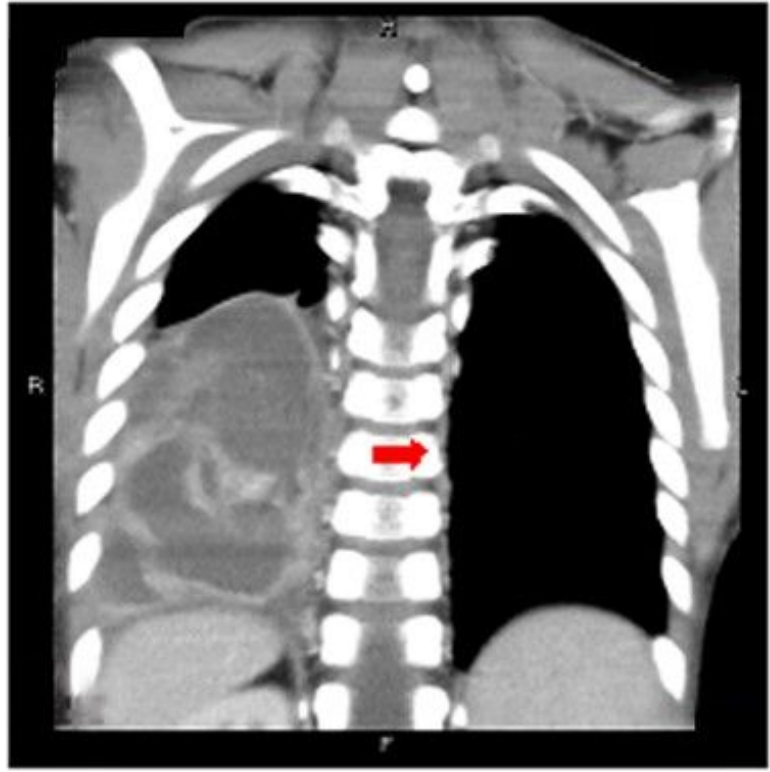

Figure 3

The preoperative CT images of case 5 (the first recurrence) showed a huge mass with a size of about $53 \times 62 \times 73$ $\mathrm{mm}$, uneven density and unclear border in the right lower lobe of lung. The enhanced CT showed uneven enhancement. 
A

B

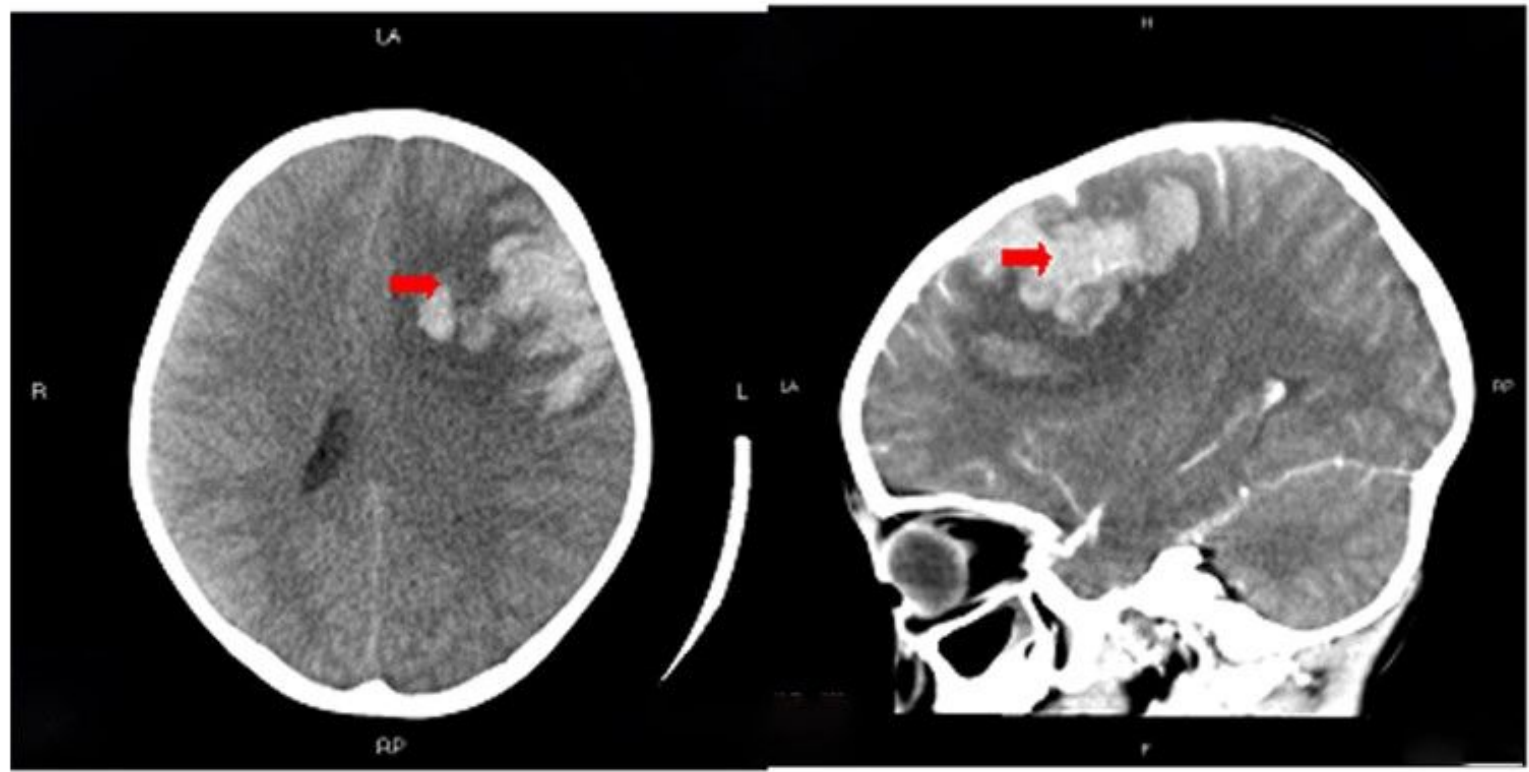

$\mathrm{C}$

D

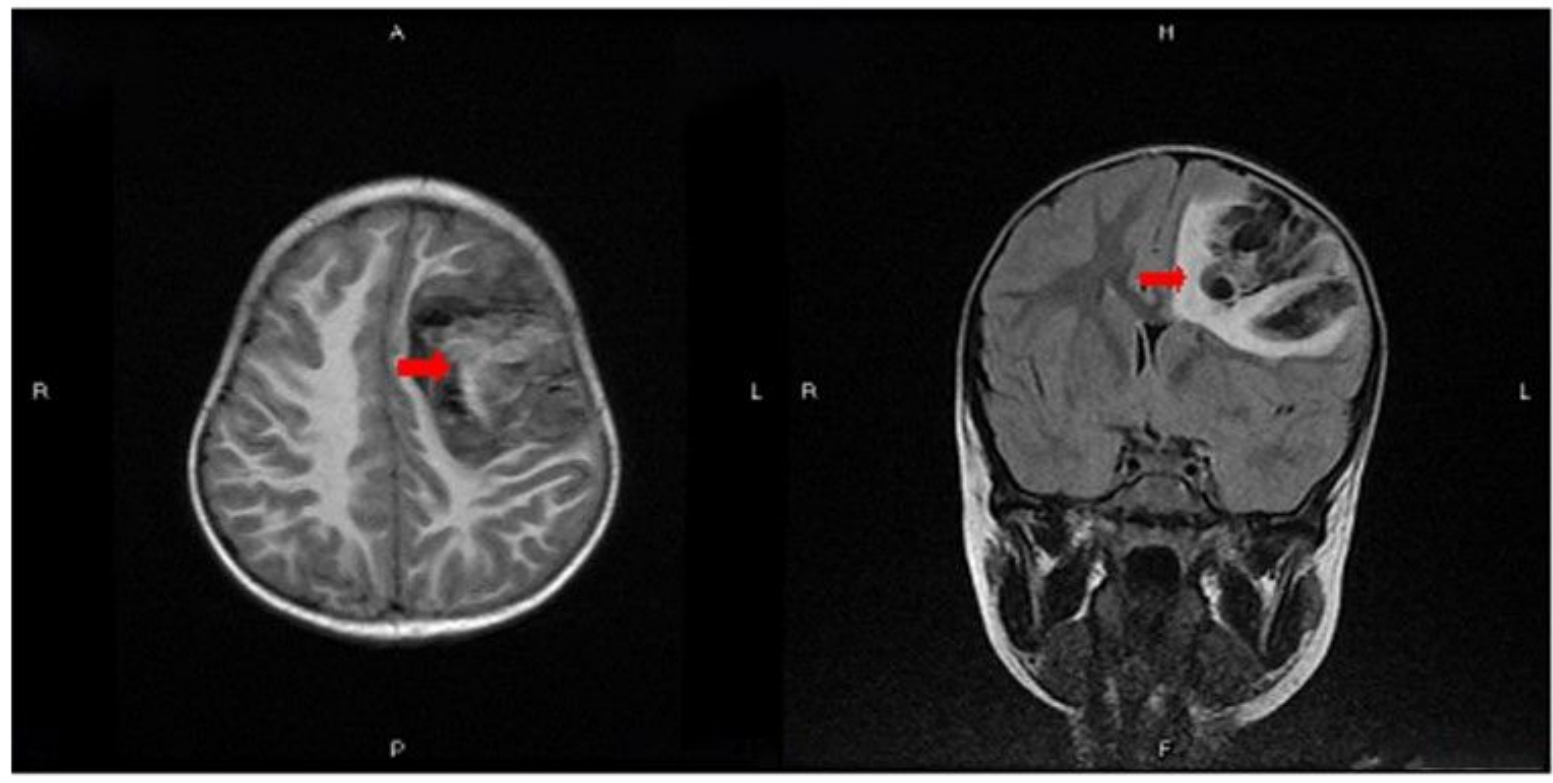

Figure 4

The imaging findings of Case 5 after cerebral hemorrhage (the third recurrence). (A-B) Head CT scans showed an irregularly shaped shadow with high density, a size of about $50 \mathrm{~mm} \times 51 \mathrm{~mm}$, clear border in the left frontal lobe. The enhanced scan showed no abnormal lesion enhancement. (C-D) Head MRI examination showed an irregular abnormal hyperintense signal with a size about $54 \mathrm{~mm} \times 65 \mathrm{~mm}$ and clear border in the left frontal lobe. T1weighted images and high signal on T2-weighted images showed mixed high and low signal. 